\title{
Electrophoretic Protein Spectra of Wild-type and Isogenic Monokaryons of Coprinus lagopus
}

\author{
By R. SMYTHE AND G. E. ANDERSON \\ Department of Biology, Liverpool Polytechnic, Byrom Street, Liverpool, L3 $3 A F$
}

(Accepted for publication I6 April I97I)

In their early investigation of the means by which the incompatibility factors of the tetrapolar basidiomycete Schizophyllum commune find physiological or biochemical expression, Raper \& Esser (196I) stressed the need to use isogenic strains to minimize differences in proteins other than those attributable to the incompatibility system. Recently Wang \& Raper (1969) have shown disc electrophoresis in polyacrylamide gel to be valuable in investigating the protein spectra of various mycelial types of this fungus and have used their results to test the validity of a model for the mode of action of the incompatibility factors. In a preliminary investigation of the applicability of disc electrophoresis to the examination of the proteins of the related fungus Coprinus lagopus sensu Buller, the method described was found to give good results. The advantage of using 'isogenic' strains of Coprinus is open to question.

\section{METHODS}

Stocks. The wild-types used were HI, H2, H6, H9, AI, A3, A9, and 68 with mating types А 5в 5, А6в 5, А5в6, А6в6, А7в7, А 8в8, А 8в7 and А 2 ві respectively. They are referred to by Day (1959, I963) and Day \& Anderson (196I). The backcrossed strains $\mathrm{BC} 9 / 55, \mathrm{BC} 9 / 65, \mathrm{BC} 9 / 56$ and $\mathrm{BC} 9 / 66$ were derived from the $\mathrm{HI}$ and H9 wild-types (by Dr D. H. Morgan of the John Innes Institute, Norwich). They were kindly supplied by Dr D. Moore (see Moore, 1966).

Method. Cultures were grown in Petri dishes on liquid complete medium (Fries, 1953) for 5 days at $28^{\circ}$. Mycelium was harvested by filtration under suction, washed, pressed dry between filter papers, weighed and stored at $-15^{\circ}$ until required. Soluble proteins were extracted as follows: about I g. fresh weight of material, after freezing at the above temperature, was ground to a fine powder using a prechilled pestle and mortar. Microscopic examination then generally showed all cells to be broken; if unbroken cells were found dry sand was added and grinding continued until cell disruption was complete. The ground material was stirred with $7 \cdot 0 \mathrm{ml}$. $0 \cdot \mathrm{I}$ M-phosphate buffer, $\mathrm{pH} 7 \cdot 2$. Debris was then removed by centrifugation at $1500 \mathrm{~g}$ for $5 \mathrm{~min}$. The supernatant was collected and ammonium sulphate added to saturation. It was then stood for $\mathbf{I} \mathbf{h}$. with occasional stirring during the first $30 \mathrm{~min}$. The precipitated protein, most of which floated to the surface, was poured off and finally separated by centrifugation at $28,000 \mathrm{~g}$ for about $\mathrm{I} h$. The temperature was $0^{\circ}$ to $5^{\circ}$ throughout. Final protein samples were stored at $-15^{\circ}$ when necessary; storage periods never exceeded $48 \mathrm{~h}$. Protein was redissolved in $\mathrm{I} \cdot 0 \mathrm{ml}$ tris-glycine buffer, $\mathrm{pH}$ approximately $7 \cdot 5$, immediately prior to electrophoresis.

The method of electrophoresis derived from that of Ornstein \& Davis (1962, I964) but was modified after Clarke (1964). This method essentially resembles the 'rod' method of Tombs \& Akroyd (1967); spacer and sample gels were omitted and the density of the sample was increased by addition of sucrose. In this investigation $7.5 \%$ gels were used with a p.d. of I $2 \mathrm{~V}$ per tube, which gives an initial current of about $2.5 \mathrm{~mA} /$ tube. 
The final protein solution from each harvest was used to prepare six replicate gels. After completion of electrophoresis the gels were stained with amido-black. Distances of all bands from the origin were recorded visually and checked by densitometry. The final protein spectrum for each of the stocks was compiled from not less than 18 gels relating to at least three different harvests. Criteria for identifying the bands were $(a) R_{p}$ values, the $R_{p}$ value for any given band being the ratio of its distance from the origin to the distance of the fastest-moving band from the origin (Fox, Thurman \& Boulter, I964), (b) direct comparisons between gels (maps of the gels drawn to scale on squared paper were found useful), and (c) positions of bands of constant appearance and intensity.

\section{RESULTS}

Differences between spectra are summarized in Table $\mathrm{I}$. During the investigation minor variations were noted between gels relating to each individual monokaryon. Variations between batches of gels most probably resulted from fluctuations in the physiological state of the organism. Minor variations between gels of the same batch can be accounted for in terms of unpredictable changes in the relative mobility of bands to which Bent (I967) drew attention. The method itself was designed to minimize alterations in structure and/ or properties of proteins during handling which could lead to changes in electrophoretic mobility. Denaturation was offset by low-temperature extraction at a $\mathrm{pH}$ near that of the culture medium and continued use of a low temperature throughout. Ammonium sulphate was chosen as a precipitant less likely to damage delicate proteins than an organic solvent such as ethanol and the higher concentration of protein produced by precipitation was advantageous.

\section{Table I. Summary of differences in protein spectra}

$R_{p}$ values of those bands in which differences were found (29\% of all bands detected) are given.

\begin{tabular}{|c|c|c|c|c|c|c|c|c|c|c|c|c|}
\hline \multirow{2}{*}{$\begin{array}{l}\text { Mean } R_{l} \\
\quad \text { value }\end{array}$} & \multicolumn{4}{|c|}{$\begin{array}{l}\text { Wild-type stocks from } \\
\text { same fruit-body }\end{array}$} & \multicolumn{4}{|c|}{ Backcrossed stocks } & \multicolumn{4}{|c|}{$\begin{array}{l}\text { Other wild-type stocks of } \\
\text { mixed origin }\end{array}$} \\
\hline & H I & $\mathrm{H} 2$ & H 6 & H9 & $9 / 55$ & $9 / 65$ & $9 / 56$ & $9 / 66$ & A I & A 3 & A 9 & 68 \\
\hline 0.07 & + & + & - & $-^{*}$ & + & + & + & + & + & + & - & + \\
\hline 0.14 & - & - & - & - & - & - & - & - & - & + & - & - \\
\hline 0.19 & + & + & + & + & - & + & + & + & + & + & - & + \\
\hline 0.39 & - & - & - & - & - & - & - & - & + & - & $-*$ & - \\
\hline 0.43 & - & - & - & - & - & - & - & - & - & - & + & + \\
\hline 0.55 & - & - & - & - & - & - & - & + & + & + & + & - \\
\hline 0.61 & - * $^{*}$ & - & + & + & - & - & - & - & - & + & - & + \\
\hline 0.62 & - & - & - & - & - & - & - & - & - & + & - & - \\
\hline 0.63 & - & - & - & - & - & - & - & - & - & + & - & - \\
\hline 0.74 & - & - & - & - & - & - & - & - & - & - & - & + \\
\hline 0.80 & + & + & + & + & + & + & + & + & + & + & $-*$ & - \\
\hline 0.86 & + & + & + & + & + & + & + & + & $-^{*}$ & + & + & + \\
\hline 0.97 & + & - & + & - & + & + & + & + & + & + & + & + \\
\hline
\end{tabular}

+ Indicates presence and - absence of a band.

* Some evidence for the existence of a band in the position indicated but that this was considered insufficient to score the band as + .

\section{DISCUSSION}

Clear differences existed between the spectra of the eight wild-types. There were considerably fewer differences between the spectra of the first group of four wild-types ( $\mathrm{H}$ [- $\mathrm{H} 9$ ) than between spectra of the third group of four (A I-68). Significantly, members of the first group were derived from the same fruit-body while members of the third group had a more 
mixed origin and were included for comparison. Of this latter group A I and A 3 were isolated from the same tetrad and the differences between their spectra were surprising, but in the absence of further data remained unexplained. Overall differences were greater than those predicted by Raper (1966) and of about the same order as those found by Wang \& Raper (1969), who used isogenic stocks. The distribution of bands of $R_{p} 0.97,0.61$ and 0.07 between the spectra of monokaryons $\mathrm{H} \mathrm{I}-\mathrm{H} 9$ could well correspond to the distribution of certain unknown genes between spores which all originated from the same fruit-body.

Backcrossing is assumed to produce isogenicity: this means that the backcrossed monokaryons should, as a group, be genetically more homogeneous than the wild-types to which they correspond except at those loci that control incompatibility. Thus one would expect the spectra of the backcrossed stocks to be more uniform than those of the corresponding parental wild-type stocks. Some evidence for this was obtained since in the case of bands of $R_{p} 0.97,0.6 \mathrm{I}$ and 0.07 the differences apparent in parental types had disappeared in the backcrossed types although in the case of bands of $R_{p} 0.55$ and 0.19 single differences had appeared. Clearly some doubt is cast on the complete isogenicity of the backcrossed stocks. The implication is that even nine generations of backcrossing is insufficient to ensure isogenicity and while this could be resolved by further backcrossing and protein analysis it is considered that the protein spectra already constructed for the monokaryons provide valid controls for comparative studies on incompatibility. The margin of advantage in using backcrossed strains is only narrow, particularly when they derive from closely related parental strains.

R.S. is grateful to the University of London Central Research Fund for a research grant.

\section{REFERENCES}

BENT, K. J. (1967). Electrophoresis of proteins of three Penicillium species on acrylamide gels. Journal of General Microbiology 49, 195-200.

Clarke, J. T. (1964). Simplified 'Disc' (polyacrylamide gel) electrophoresis. Annals of the New York Academy of Sciences 121, 428-436.

DAY, P. R. (1959). A cytoplasmically controlled abnormality of the tetrads of Coprinus lagopus. Heredity 13, $8 \mathrm{I}-87$.

DAY, P. R. (1963). The structure of the A mating type factor in Coprinus lagopus: Wild alleles. Genetical Research, Cambridge 4, 323-325.

DAY, P. R. \& ANDERson, G. E. (1961). Two linkage groups in Coprinus lagopus. Genetical Research, Cambridge 2, 414-423.

Fox, D. J., Thurman, D. A. \& Boulter, D. (1964). Studies on the proteins of the seeds of the Leguminoseae. I. Albumins. Phytochemistry 3, 417-419.

FrIES, L. (I953). Factors promoting growth of Coprinus fimetarius (L) under high temperature conditions. Physiologia Plantarum 6, 55I-563.

Moore, D. (I966). The formal genetics of Coprinus lagopus (sensu Buller). Ph.D. thesis, University of Hull.

ORnsteIn, L. \& DAVIS, B. J. (1962). Disc Electrophoresis. Brochure from Distillation Products Industries, Rochester, New York and Canalco, Bethesda, Maryland.

ORnSteIN, L. \& DAVIs, B. J. (1964). Disc electrophoresis. I. Background and theory. II. Method and application to human serum proteins. Annals of the New York Academy of Sciences 121, 32 I-349, 404-427.

RAPER, J. R. (1966). Genetics of Sexuality in Higher Fungi. New York: Ronald Press.

RAPER, J. R. \& ESSER, K. (196I). Antigenic differences due to the incompatibility factors in Schizophyllum commune. Zeitschrift für Vererbungslehre 92, 439-444.

TOMBS, M. P. \& AKRoYD, P. (1967). Acrylamide Gel Electrophoresis. Shandon Monographs on Modern Scientific Techniques no. 18 .

WANG, C.-S. \& RAPER, J. R. (1969). Protein specificity and sexual morphogenesis in Schizophyllum commune. Journal of Bacteriology 99, 291-297. 